\title{
Intestinal Epithelial Cell Injury Is Rescued By Hydrogen Sulfide
}

\author{
Bo Li ${ }^{1 *}$, Augusto Zani ${ }^{*}$, Zechariah Martin ${ }^{1}$, Carol Lee ${ }^{1}$, \\ Elke Zani-Ruttenstock ${ }^{1}$, Simon Eaton ${ }^{2}$, Agostino Pierro $^{1}$
}

\footnotetext{
${ }^{1}$ Division of General and Thoracic Surgery, Physiology and Experimental Medicine Program, The Hospital for Sick Children, Toronto, ON, Canada

${ }^{2}$ UCL Institute of Child Health, London, United Kingdom

* Joint first authorship
}

\section{Corresponding author:}

Dr. Agostino Pierro, OBE, MD, FRCS(Engl), FRCS(Ed), FAAP

Division Head, Paediatric Surgery

Robert M. Filler Professor of Surgery

University of Toronto, Canada

The Hospital for Sick Children

1526-555 University Ave

Toronto, ON M5G 1X8, Canada

Phone +14168137340

Fax $+1416-813-7477$

Email: agostino.pierro@ sickkids.ca 


\section{Abstract}

Background/Purpose: Oxidative stress is implicated in the pathogenesis of necrotizing enterocolitis (NEC). Hydrogen sulfide $\left(\mathrm{H}_{2} \mathrm{~S}\right)$ has been reported to have a protective function against oxidative stress in the gut. We hypothesize that administration of $\mathrm{H}_{2} \mathrm{~S}$ can help decrease intestinal epithelial cell injury in vitro.

Methods: Intestinal epithelial cells (IEC-18) were treated with $200 \mu \mathrm{M}$ hydrogen peroxide $\left(\mathrm{H}_{2} \mathrm{O}_{2}\right)$ for 21 hours. At 21 hours sodium hydrosulfide (NaHS), a $\mathrm{H}_{2} \mathrm{~S}$ donor, was administered as a rescue treatment at two different concentrations: $0.1 \mathrm{mM}$ and $0.2 \mathrm{mM}$. At 24 hours, cell viability was measured using a colorimetric assay (MTT). Oxidative stress was studied by glutathione peroxidase (GPx) activity and thiobarbituric acid reactive substances (TBARS). IL-6 and TNF $\alpha$ levels were tested to study inflammation. Data were presented as mean \pm SD and compared using one-way ANOVA with Bonferroni post-test.

Results: Compared to control, $\mathrm{H}_{2} \mathrm{O}_{2}$-treated IEC-18 had reduced viability $(\mathrm{p}<0.01)$, lower GPx activity $(\mathrm{p}<0.01)$, higher TBARS levels $(\mathrm{p}<0.01)$, and increased IL6 and TNF $\alpha(p<0.001)$. Compared to $\mathrm{H}_{2} \mathrm{O}_{2}$-treated IEC-18, treatment with $0.2 \mathrm{mM} \mathrm{NaHS}$ rescued viability $(\mathrm{p}<0.01)$, increased GPx activity $(\mathrm{p}<0.05)$, and reduced TBARS $(\mathrm{p}<0.01)$, IL6 and TNF $\alpha(\mathrm{p}<0.001)$.

Conclusions: $\mathrm{H}_{2} \mathrm{~S}$ successfully rescues epithelial cell damage induced by oxidative stress in vitro. This indicates that $\mathrm{H}_{2} \mathrm{~S}$ could be a potential pharmacological intervention in conditions like NEC.

Keywords: Necrotizing enterocolitis; NEC; colitis; $\mathrm{H}_{2} \mathrm{~S}$; NaHS; oxidative stress 


\section{Introduction}

In premature infants, oxidative stress is considered one of the primary mechanisms involved in the pathogenesis of diseases such as retinopathy of prematurity, chronic lung disease, and necrotizing enterocolitis (NEC) [1]. These patients have lowefficient antioxidant systems that fail to counteract the harmful effects of oxidative stress-generated reactive oxygen species (ROS). A direct link between ROS production in the premature gut and NEC development has been suggested [2-4]. There is experimental evidence that NEC evolves from disruption of the intestinal epithelial barrier, due to production of reactive nitrogen derivatives such as peroxynitrite that induce enterocyte apoptosis, necrosis and damage the tight and gap junctions, thus altering gut permeability [5]. The exaggerated inflammatory response leads to upregulation of the inducible form of nitric oxide synthase (iNOS) within the mucosa. As a result, some investigators have proposed treatment strategies that are aimed at abrogating iNOS production [6]. Ciftci et al demonstrated that administration of aminoguanidine, which is an inhibitor of iNOS, decreased tissue levels of reactive nitrogen species and improves intestinal inflammatory damage in a neonatal rat model of NEC [7]. Similarly, Zuckerbraun et al showed that exposure to carbon monoxide both in vitro (enterocyte cell line) and in vivo (neonatal rat model) resulted in decreased iNOS production, reduced serum levels of pro-inflammatory cytokines, and decreased apoptosis rate [8]. Moreover, human studies have shown that formula supplementation with L-Arginine, a nitric oxide donor, could be beneficial in preventing NEC development in preterm infants $[\mathbf{9 , 1 0}]$, although the data are not sufficient to support a practice recommendation $[\mathbf{1 1 , 1 2}]$.

In search for novel treatment agents that could offset oxidative stress induced bowel 
damage in preterm infants with NEC, we focused on hydrogen sulfide $\left(\mathrm{H}_{2} \mathrm{~S}\right) . \mathrm{H}_{2} \mathrm{~S}$ is an endogenously produced gaseous mediator which is a key regulator in physiological and pathological processes in various systems including the gastrointestinal tract [1317]. $\mathrm{H}_{2} \mathrm{~S}$ has an anti-inflammatory and cytoprotective function, and contributes to mucosal defense against infection in the gastrointestinal tract [18]. Its protective role has been confirmed by studies in models of experimental colitis showing that on the one hand inhibition of $\mathrm{H}_{2} \mathrm{~S}$ synthesis leads to mucosal inflammation, increased susceptibility to injury, and impaired healing and on the other hand administration of $\mathrm{H}_{2} \mathrm{~S}$ donors accelerate healing and exert significant anti-inflammatory effects [19-22].

In the present study, we aimed to investigate whether $\mathrm{H}_{2} \mathrm{~S}$ could be beneficial against intestinal epithelium injury induced by oxidative stress using an intestinal epithelial cell line.

\section{Methods}

\section{Cells and study groups}

A rat small intestinal epithelial cell line, IEC-18, was purchased from the American Type Culture Collection (ATCC, Manassas, VA) and maintained in Dulbecco's modified Eagle's medium with high glucose (DMEM, Gibco BRL) supplemented with $10 \%$ fetal bovine serum (FBS, GibcoBRL) and $100 \mathrm{mg} / \mathrm{ml}$ penicillin and streptomycin (Sigma-Aldrich). Cells were cultured at $37^{\circ} \mathrm{C}$ in a humidified atmosphere with $5 \% \mathrm{CO}_{2}$.

For all experiments presented herein, there were four study groups: 
i. $\quad$ Control- IEC-18 were exposed to medium alone as control

ii. $\quad \underline{\mathrm{H}}_{2} \underline{\mathrm{O}}_{2}-$ - IEC-18 were treated with $200 \mu \mathrm{M}$ hydrogen peroxide $\left(\mathrm{H}_{2} \mathrm{O}_{2}\right)$ for 21 hours to mimic intestinal epithelial injury.

iii. $\quad$ NaHS low concentration - IEC-18 were treated with $200 \mu \mathrm{M} \mathrm{H}_{2} \mathrm{O}_{2}$ for 21 hours and NaHS 0.1mM was added for additional 3 hours (total 24 hour experiment)

iv. NaHS high concentration - IEC-18 were treated with $200 \mu \mathrm{M} \mathrm{H}_{2} \mathrm{O}_{2}$ for 21 hours and NaHS 0.2mM was added for additional 3 hours (total 24 hours)

\section{Cell viability}

IEC-18 cell viability was tested using a colorimetric assay that detects the conversion of MTT into formazan by the mitochondrial enzyme succinate dehydrogenase. After treatment, $0.5 \mathrm{mg} / \mathrm{ml} \mathrm{MTT} \mathrm{(ATCC,} \mathrm{Manassas,} \mathrm{VA)} \mathrm{was} \mathrm{added} \mathrm{to} \mathrm{the} \mathrm{medium} \mathrm{for} 3$ hour incubation, the insoluble formazan crystals within the cells were extracted by DMSO, and the absorbance was measured using a micro-plate reader (Molecular Devices SpectraMax Gemini EM) at a wavelength of $570 \mathrm{~nm}$.

\section{Oxidative stress}

To investigate the effects of oxidative stress induced by $\mathrm{H}_{2} \mathrm{O}_{2}$, we measured glutathione peroxidase (GPx) activity and thiobarbituric acid reactive substances (TBARS) in IEC-18 cells. Both were normalized to protein, measured by BCA protein assay kit (Thermo Scientific, USA). GPX activity in cell lysate was measured using a commercial test kit (Cayman Chemical Company, Michigan) according to the manufacturer's instructions. Briefly, GPx catalyzed the oxidation of glutathione (GSH) by hydroperoxide. In the presence of glutathione reductase and NAPDH, the oxidized glutathione is immediately converted to the reduced form with a concomitant 
oxidation of NAPDH to NAPD+. The decreased in absorbance at 340nm was measured by a micro-plate reader (Molecular Devices SpectraMax Gemini EM). The specific activity for GPx was expressed in units per milligram protein (U/mg protein). TBARS were measured in the cell lysate (Cayman Chemical Company, Michigan). Briefly, tricholoroacetic in sodium sulfate was added into cell lysates. After precipitation, the samples were washed by sulfuric acid and then incubated in a boiling water bath for one hour. After cooling, the samples were extracted with $n$ butanol and centrifuged for 10 minutes at $1600 \mathrm{x}$ g at $4^{\circ} \mathrm{C}$. Absorbance was measured using a micro-plate reader (Molecular Devices SpectraMax Gemini EM) at a wavelength of $540 \mathrm{~nm}$.

\section{Inflammation}

To study the effects of NaHS on inflammation, pro-inflammatory cytokines IL-6 and $\mathrm{TNF} \alpha$ levels were measured in the cell supernatant using ELISA (IL-6: Sigma, MO, USA; TNFa: Thermo Scientific, USA). Absorbance was measured using a microplate reader (Molecular Devices SpectraMax Gemini EM) at a wavelength of 450 nm.

\section{Statistics}

Results are presented as mean \pm SD according to normality of data distribution (Kolmogorov-Smirnov test). Data were compared using one-way ANOVA with Bonferroni post-test. $\mathrm{P}<0.05$ was considered significant. 


\section{Results}

\section{Cell viability}

Cells treated with $\mathrm{H}_{2} \mathrm{O}_{2}$ had decreased viability compared to control $(0.29 \pm 0.04$ vs. $0.44 \pm 0.03, \mathrm{p}<0.01$; Figure 1). Cell viability was not increased by the addition of $0.1 \mathrm{mM}$ NaHS $(0.34 \pm 0.05, \mathrm{p}=$ n.s. to control $)$, but it was rescued by $0.2 \mathrm{mM} \mathrm{NaHS}$ $\left(0.42 \pm 0.09 ; \mathrm{p}<0.01\right.$ to $\mathrm{H}_{2} \mathrm{O}_{2} ; \mathrm{p}=$ n.s. to control; Figure 1).

\section{Oxidative stress}

Treatment with $\mathrm{H}_{2} \mathrm{O}_{2}$ significantly decreased GPx activity in comparison to control (65.6 $\pm 27.6 \mathrm{U} / \mathrm{mg}$ vs. 139.6 $\pm 46.1 \mathrm{U} / \mathrm{mg}, \mathrm{p}<0.01$; Figure 2A). GPx activity was not significantly improved by $0.1 \mathrm{mM}$ NaHS treatment $\left(122.8 \pm 9.8 \mathrm{U} / \mathrm{mg}\right.$, $\mathrm{p}=$ n.s. to $\mathrm{H}_{2} \mathrm{O}_{2}$; Figure 2A), but was rescued by $0.2 \mathrm{mM}$ NaHS $\left(136.6 \pm 29.5 \mathrm{U} / \mathrm{mg} ; \mathrm{p}<0.01\right.$ to $\mathrm{H}_{2} \mathrm{O}_{2} ; \mathrm{p}=$ n.s. to control; Figure 2A). TBARS levels were significantly increased in $\mathrm{H}_{2} \mathrm{O}_{2}$ treated cells compared to control $(0.57 \pm 0.1 \mu \mathrm{M}$ MDA equivalents vs. $0.2 \pm 0.2 \mu \mathrm{M}$, $\mathrm{p}<0.01$; Figure 2B). Treatment with $0.1 \mathrm{mM}$ NaHS did not decrease TBARS levels $\left(0.37 \pm 0.06 \mu \mathrm{M}, \mathrm{p}=\right.$ n.s. to $\mathrm{H}_{2} \mathrm{O}_{2} ;$ Figure $\left.2 \mathbf{B}\right)$, which were instead significantly reduced by $0.2 \mathrm{mM}$ NaHS treatment $\left(0.11 \pm 0.09 \mu \mathrm{M}, \mathrm{p}<0.001\right.$ to $\mathrm{H}_{2} \mathrm{O}_{2} ; \mathrm{p}=\mathrm{ns}$ to control; Figure 2B).

\section{Inflammation}

$\mathrm{H}_{2} \mathrm{O}_{2}$ significantly increased supernatant IL-6 levels compared to control $(2537 \pm 367 \mathrm{pg} / \mathrm{ml}$ vs. $198 \pm 62 \mathrm{pg} / \mathrm{ml}, \mathrm{p}<0.01$; Figure 3A). Conversely, compared with $\mathrm{H}_{2} \mathrm{O}_{2}$ both $0.1 \mathrm{mM}$ NaHS and $0.2 \mathrm{mM}$ NaHS treatments decreased IL-6 levels $(0.1 \mathrm{mM}$ NaHS: $1593 \pm 130 \mathrm{pg} / \mathrm{ml}, \mathrm{p}<0.01$ to $\mathrm{H}_{2} \mathrm{O}_{2} ; 0.2 \mathrm{mM} \mathrm{NaHS:} 820 \pm 83 \mathrm{pg} / \mathrm{ml}, \mathrm{p}<0.001$ to $\mathrm{H}_{2} \mathrm{O}_{2}$; Figure 3A). Similarly, TNF $\alpha$ levels were increased in $\mathrm{H}_{2} \mathrm{O}_{2}$ compared to 
control $(2537 \pm 367 \mathrm{pg} / \mathrm{ml}$ vs. $198 \pm 62 \mathrm{pg} / \mathrm{ml} ; \mathrm{p}<0.01 ;$ Figure 3B), and were significantly decreased by both $0.1 \mathrm{mM}$ NaHS and $0.2 \mathrm{mM}$ NaHS compared to $\mathrm{H}_{2} \mathrm{O}_{2}$ (0.1mM NaHS: $1593 \pm 130 \mathrm{pg} / \mathrm{ml}, \mathrm{p}<0.01$ to $\mathrm{H}_{2} \mathrm{O}_{2} ; 0.2 \mathrm{mM}$ NaHS: $820 \pm 83 \mathrm{pg} / \mathrm{ml}$, $\mathrm{p}<0.001$ to $\mathrm{H}_{2} \mathrm{O}_{2}$; Figure 3B).

\section{Discussion}

The present study indicates that $\mathrm{H}_{2} \mathrm{~S}$ has the potential of rescuing the intestinal epithelial cell damage induced by oxidative stress.

Epithelial damage was successfully modelled in vitro using $\mathrm{H}_{2} \mathrm{O}_{2}$, as verified by the effects on cell viability. This is a well-established model of epithelial injury induced by oxidative stress and it relies on the evidence that ROS, particularly $\mathrm{H}_{2} \mathrm{O}_{2}$, cause epithelial permeability changes and mucosal injury in small intestinal cell lines [2324]. In our experiments, the epithelial damage induced by $\mathrm{H}_{2} \mathrm{O}_{2}$ was rescued when the cells were treated with a higher concentration of NaHS that significantly improved cell viability. This is in line with other studies that have shown how $\mathrm{H}_{2} \mathrm{~S}$ donors such as NaHS may have a protective effect on the intestinal mucosa [25-28]. The mechanism through which NaHS is protective against oxidative stress-induced intestinal injury can be related to the attenuation of ROS level and inflammation.

To investigate the effects of oxidative stress induced by $\mathrm{H}_{2} \mathrm{O}_{2}$, we measured glutathione peroxidase activity and TBARS in IEC-18 cells and found that NaHS treatment at a higher concentration acted effectively as anti-oxidant. Glutathione peroxidase function is to reduce lipid hydroperoxides to their corresponding alcohols and to reduce free $\mathrm{H}_{2} \mathrm{O}_{2}$ to water. Several studies have reported the same effect in the intestine. Liu et al demonstrated that NaHS treatment in a model of intestinal 
ischemia/reperfusion injury could significantly reduce the severity of bowel damage by increasing glutathione peroxidase activity in both serum and intestinal tissue [29]. A similar effect was reported by Henderson et al, who were able to attenuate ischemia/reperfusion small bowel injury both in vitro and in vivo via administration of NaHS after the onset of ischemia [30].

We also investigated TBARS amount and found that this was significantly increased when IEC-18 were exposed to $\mathrm{H}_{2} \mathrm{O}_{2}$ and recovered when higher concentrations of NaHS were employed. TBARS are end products of lipid peroxidation, which refers to the oxidative degradation of lipids. In this process, ROS steal electrons from the lipids in cell membranes, resulting in cell damage.

Finally we investigated whether the $\mathrm{H}_{2} \mathrm{O}_{2}$ induced intestinal epithelial damage resulted in release of inflammatory cytokines and whether this phenomenon was reversed by administration of NaHS. In the present study both concentrations of NaHS reduced IL- 6 and TNF- $\alpha$ levels in IEC-18 supernatant. $\mathrm{H}_{2} \mathrm{~S}$ has been reported to be a modulator of inflammatory processes in various systems, including the gastrointestinal tract. In animal models of inflammation and inflammation-related pain, $\mathrm{H}_{2} \mathrm{~S}$ has proven to exert protective effects by reducing edema formation via effects on $\mathrm{K}_{\mathrm{ATP}}$ channels [31]. Moreover, it has been shown that $\mathrm{H}_{2} \mathrm{~S}$ donors are able to inhibit leukocyte infiltration and that inhibition of $\mathrm{H}_{2} \mathrm{~S}$ synthesis promotes leukocyte infiltration [31].

$\mathrm{H}_{2} \mathrm{~S}$ seems to be protective against oxidative stress and inflammation, which are pathological processes that typically affect a preterm intestine. These beneficial effects of $\mathrm{H}_{2} \mathrm{~S}$ on a small intestinal cell line represent a proof of concept for a promising novel treatment in a neonatal intestinal disease such as NEC. Theoretically, $\mathrm{H}_{2} \mathrm{~S}$ could be useful in the initial stages of NEC, i.e. Bell stage 1 or 2 , before the 
intestinal inflammatory process is so advanced that surgery would be required. However, to translate this observation into clinical practice, further studies are needed to confirm the present findings in an in vivo model of NEC.

In conclusion, in this in vitro study we have demonstrated that intestinal cell viability is impaired by exposure to $\mathrm{H}_{2} \mathrm{O}_{2}$, which mimics the oxidative stress on the intestinal epithelium. This damage can be reversed by treatment with $\mathrm{NaHS}$, an $\mathrm{H}_{2} \mathrm{~S}$ donor that prevents oxidative damage and acts an anti-inflammatory agent. These findings indicate the potential for a pharmacological intervention to rescue the intestinal epithelium in intestinal pathological conditions such as NEC. 


\section{Acknowledgements}

This work was supported by the endowment of the Robert M Filler Chair of Surgery, The Hospital for Sick Children. SE is supported by Great Ormond Street Hospital Children's Charity. 


\section{$\underline{\text { References }}$}

[1] Dennery PA: Role of redox in fetal development and neonatal diseases. Antioxid Redox Signal 2004;6:147-153.

[2] Clark DA, Fornabaio DM, McNeill H, et al: Contribution of oxygen-derived free radicals to experimental necrotizing enterocolitis. Am J Pathol 1988;130:537-542.

[3] Okur H, Küçükaydin M, Köse K, et al: Hypoxia-induced necrotizing enterocolitis in the immature rat: the role of lipid peroxidation and management by vitamin $\mathrm{E}$. J Pediatr Surg 1995;30:1416-1419.

[4] Kelly N, Friend K, Boyle P, et al: The role of the glutathione antioxidant system in gut barrier failure in a rodent model of experimental necrotizing enterocolitis. Surgery 2004;136:557-566.

[5] Chokshi NK, Guner YS, Hunter CJ, et al: The role of nitric oxide in intestinal epithelial injury and restitution in neonatal necrotizing enterocolitis. Semin Perinatol 2008;32:92-99.

[6] Guner YS, Chokshi N, Petrosyan M, et al: Necrotizing enterocolitis--bench to bedside: novel and emerging strategies. Semin Pediatr Surg 2008;17:255-265.

[7] Ciftci I, Dilsiz A, Aktan TM, et al: Effects of nitric oxide synthase inhibition on intestinal damage in rats with experimental necrotizing enterocolitis. Eur $\mathbf{J}$ Pediatr Surg 2004;14:398-403.

[8] Zuckerbraun BS, Otterbein LE, Boyle P, et al: Carbon monoxide protects against the development of experimental necrotizing enterocolitis. Am J Physiol Gastrointest Liver Physiol 2005;289:G607-G613.

[9] Amin HJ, Zamora SA, McMillan DD, et al: Arginine supplementation prevents necrotizing enterocolitis in the premature infant. J Pediatr 2002;140:425-431.

[10] Polycarpou E, Zachaki S, Tsolia M, et al: Enteral L-arginine supplementation for prevention of necrotizing enterocolitis in very low birth weight neonates: a double-blind randomized pilot study of efficacy and safety. JPEN J Parenter Enteral Nutr 2013;37:617-622. 
[11] Shah P, Shah V: Arginine supplementation for prevention of necrotizing enterocolitis in preterm infants. Cochrane Database Syst Rev 2007;3:CD004339.

[12] Mitchell K, Lyttle A, Amin H, et al: Arginine supplementation in prevention of necrotizing enterocolitis in the premature infant: an updated systematic review. BMC Pediatr 2014;14:226.

[13] Szabó C: Hydrogen sulphide and its therapeutic potential. Nat Rev Drug Discov 2007;6:917-935.

[14] Kasparek MS, Linden DR, Kreis ME, et al: Gasotransmitters in the gastrointestinal tract. Surgery. 2008;143:455-459.

[15] Kasparek MS, Linden DR, Farrugia G, et al: Hydrogen sulfide modulates contractile function in rat jejunum. J Surg Res 2012;175:234-242.

[16] Kimura H: Production and physiological effects of hydrogen sulfide. Antioxid Redox Signal 2014;20:783-793.

[17] Wu D, Wang J, Li H, et al: Role of Hydrogen Sulfide in Ischemia-Reperfusion Injury. Oxid Med Cell Longev 2015;2015:186908.

[18] Wallace JL, Blackler RW, Chan MV, et al: Anti-inflammatory and cytoprotective actions of hydrogen sulfide: translation to therapeutics. Antioxid Redox Signal 2015;22:398-410.

[19] Fiorucci S, Orlandi S, Mencarelli A, et al: Enhanced activity of a hydrogen sulphide-releasing derivative of mesalamine (ATB-429) in a mouse model of colitis. Br J Pharmacol 2007;150:996-1002.

[20] Wallace JL, Vong L, McKnight W, et al: Endogenous and exogenous hydrogen sulfide promotes resolution of colitis in rats. Gastroenterology 2009;137:569-578.

[21] Flannigan KL, Ferraz JG, Wang R, et al: Enhanced synthesis and diminished degradation of hydrogen sulfide in experimental colitis: A site-specific, pro- 
resolution mechanism. PLoS ONE 2013;8:e71962.

[22] Flannigan KL, Agbor TA, Blackler RW, et al: Impaired hydrogen sulfide synthesis and IL-10 signaling underlie hyperhomocysteinemia-associated exacerbation of colitis. Proc Natl Acad Sci U S A 2014;111:13559-13564.

[23] Ma TY, Hollander D, Freeman D, et al: Oxygen free radical injury of IEC-18 small intestinal epithelial cell monolayers. Gastroenterology 1991;100(6):15331543.

[24] Mao L, Chen J, Peng Q, et al: Effects of different sources and levels of zinc on H2O2-induced apoptosis in IEC-6 cells. Biol Trace Elem Res 2013;155:132-141.

[25] Distrutti E, Sediari L, Mencarelli A, et al: Evidence that hydrogen sulfide exerts antinociceptive effects in the gastrointestinal tract by activating KATP channels. J Pharmacol Exp Ther 2006;316:325-335.

[26] Matsunami M, Kirishi S, Okui T, et al: Hydrogen sulfide-induced colonic mucosal cytoprotection involves T-type calcium channel-dependent neuronal excitation in rats. J Physiol Pharmacol 2012;63:61-68.

[27] Pan H, Chen D, Liu B, et al: Effects of sodium hydrosulfide on intestinal mucosal injury in a rat model of cardiac arrest and cardiopulmonary resuscitation. Life Sci 2013;93:24-29.

[28] Gade AR, Kang M, Akbarali HI: Hydrogen sulfide as an allosteric modulator of ATP-sensitive potassium channels in colonic inflammation. Mol Pharmacol 2013;83:294-306.

[29] Liu H, Bai XB, Shi S, et al: Hydrogen sulfide protects from intestinal ischaemiareperfusion injury in rats. J Pharm Pharmacol 2009;61:207-212.

[30] Henderson PW, Weinstein AL, Sohn AM, et al: Hydrogen sulfide attenuates intestinal ischemia-reperfusion injury when delivered in the post-ischemic period. 
J Gastroenterol Hepatol 2010;25:1642-1647.

[31] Zanardo RC, Brancaleone V, Distrutti E, et al: Hydrogen sulfide is an endogenous modulator of leukocyte-mediated inflammation. FASEB $\mathbf{J}$ 2006;20:2118-2120. 


\section{Figure legends}

Figure 1: IEC-18 viability measured by MTT assay.

Figure 2: Oxidative stress - A) Glutathione peroxidase (GPx) activity of IEC-18 measured by GPx Assay kit. B) Thiobarbituric acid reactive substances (TBARS) levels of IEC-18 measured by TBARS Assay kit.

Figure 3: Inflammation - A) IL-6 levels from IEC-18 cell supernatant. B) TNF $\alpha$ levels from IEC-18 cell supernatant. 
Figure 1

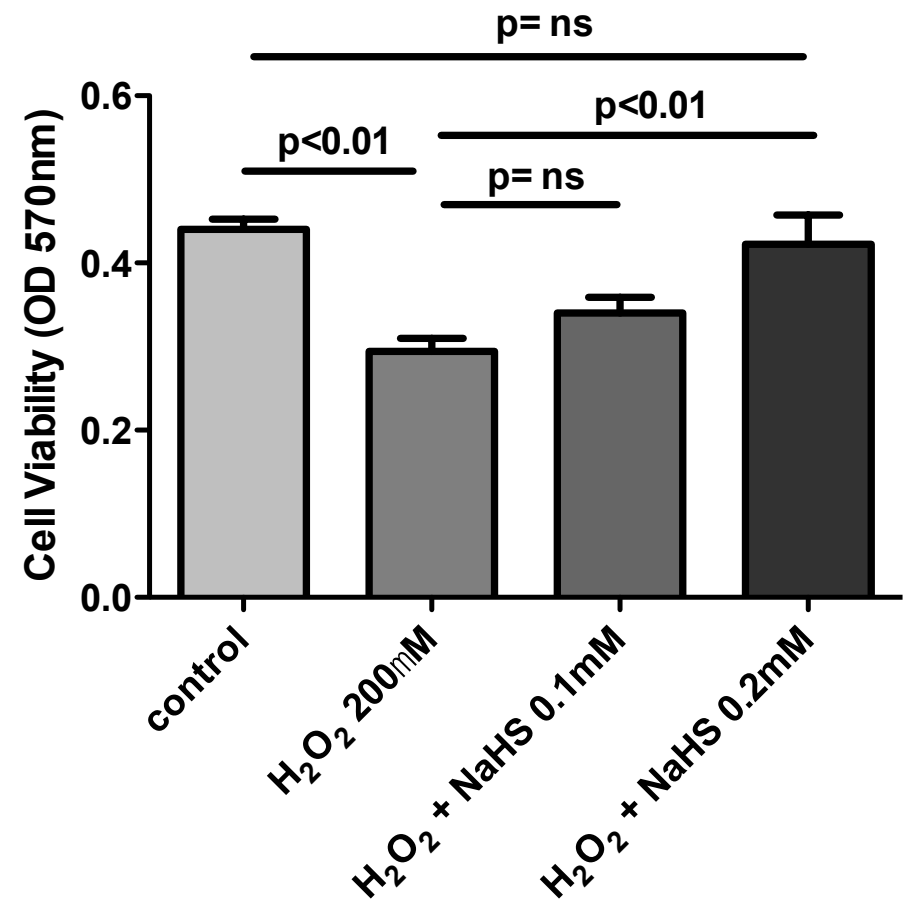


Figure 2

A

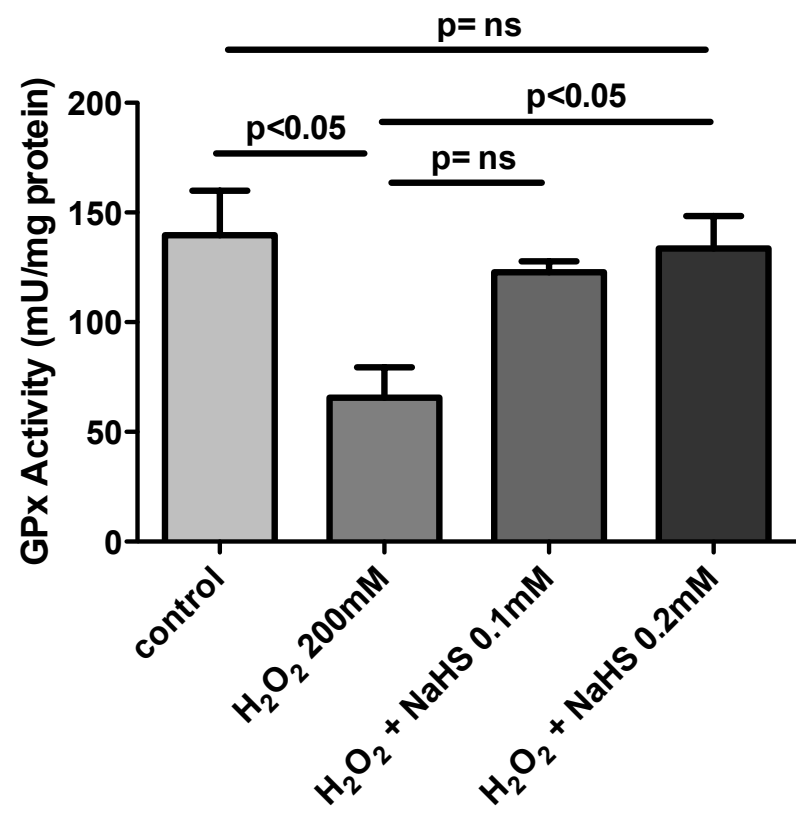

B

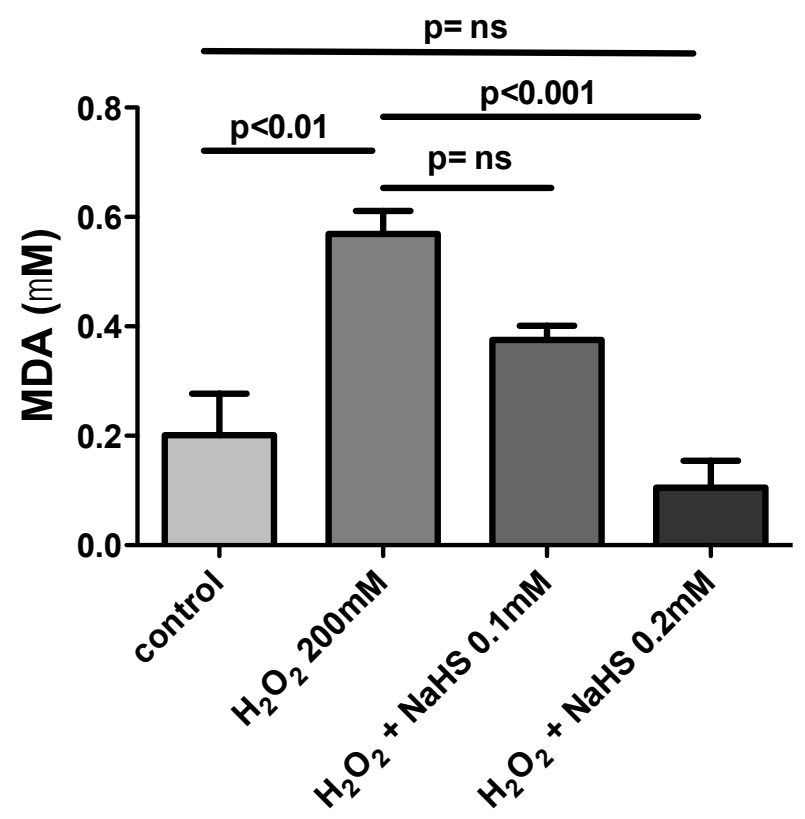


Figure 3

A

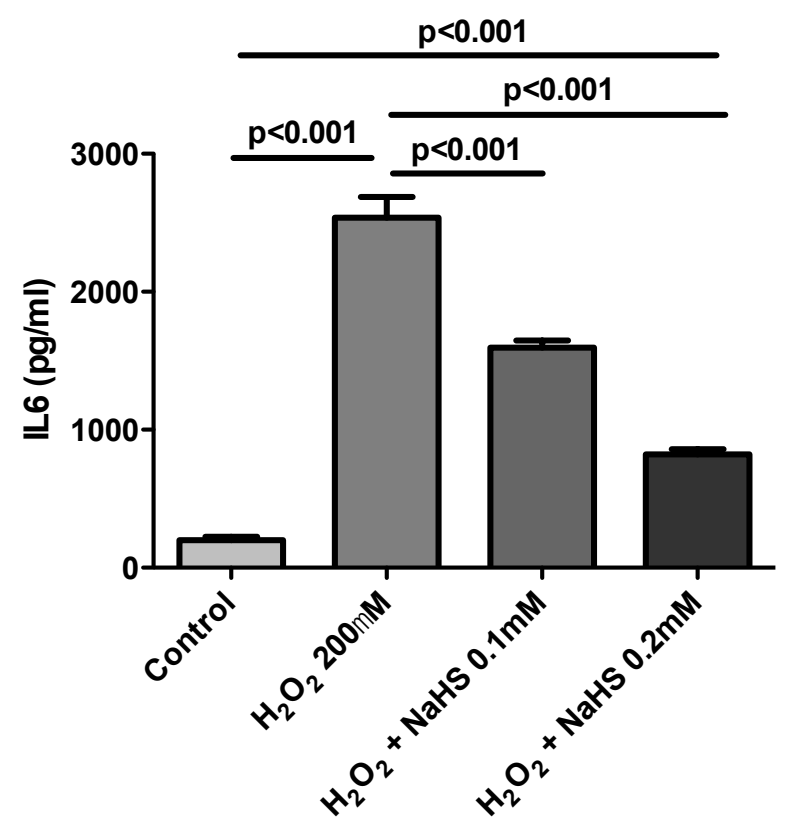

B

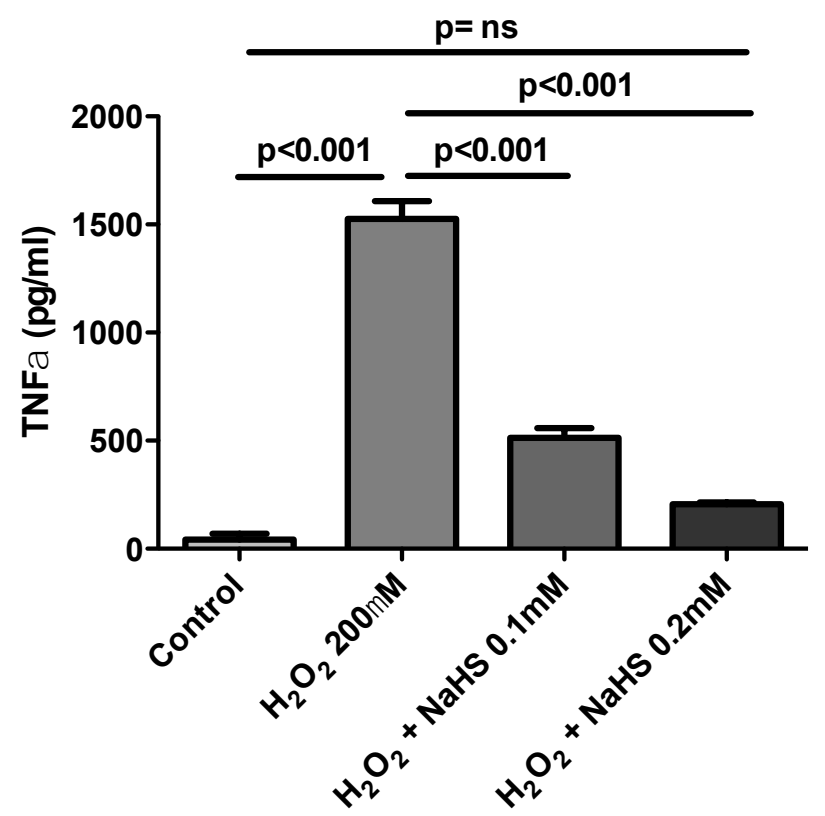

